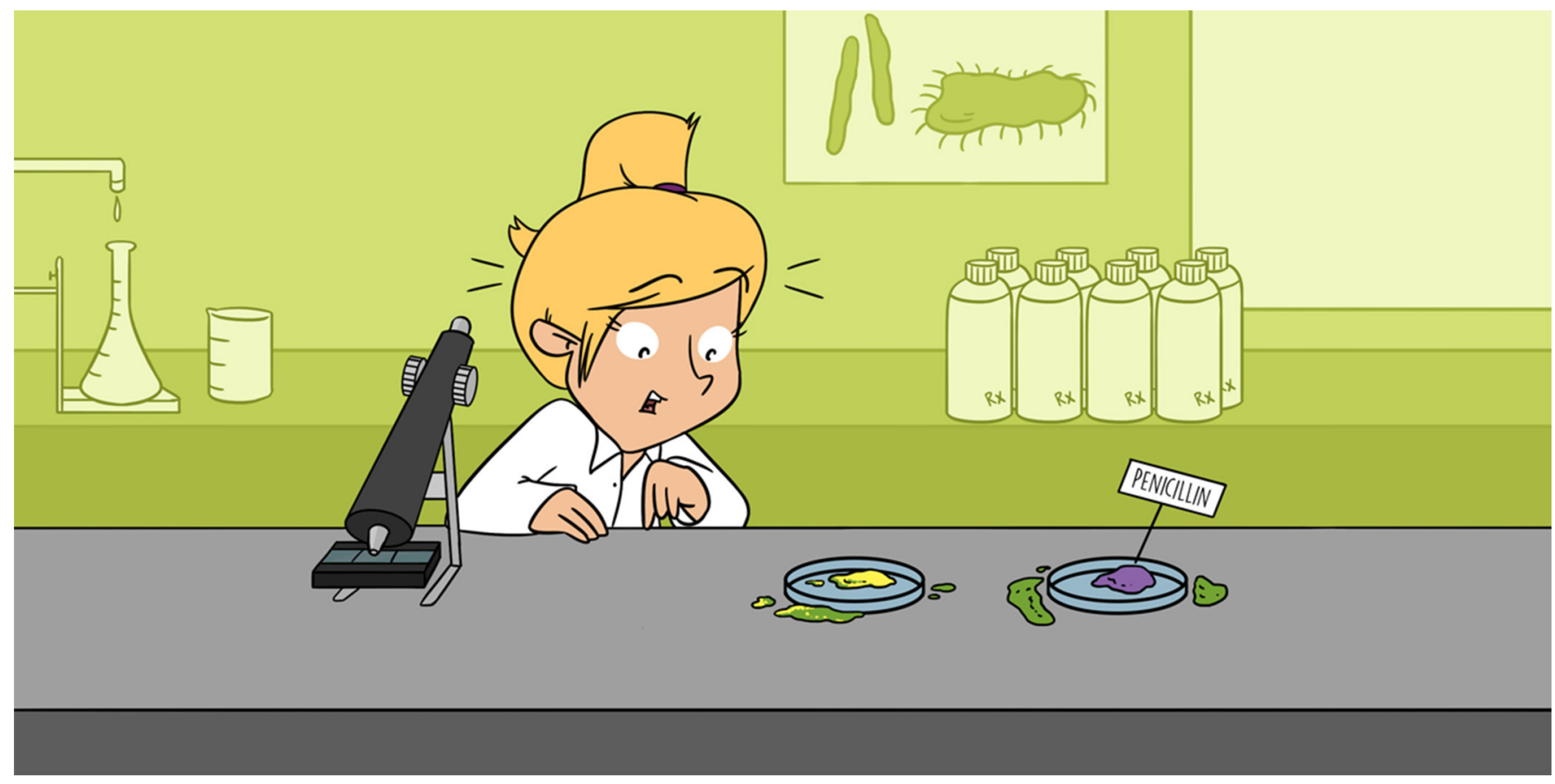

\title{
ALEXANDER FLEMING, THE DISCOVERER OF THE ANTIBIOTIC EFFECTS OF PENICILLIN
}

\section{Michal Letek ${ }^{* t}$}

Health Sciences Research Centre, University of Roehampton, London, United Kingdom

YOUNG REVIEWERS:

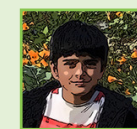

ANJISHNU

AGE: 12

ENZO

AGE: 15
In 1928, Sir Alexander Fleming observed the bacterial-killing effects of penicillin in his laboratory in London. This was the first step in the discovery of one of the most important pillars of today's medicine: the antibiotics. It took many years to find a way to produce penicillin in large amounts, and large-scale production did not start until 1945. However, to this day, Fleming is considered the father of the antibiotics, and without his discovery we could not treat many infections caused by bacteria. This means that, without antibiotics, even a small infected wound could become fatal. In addition, surgery is much safer with antibiotics, and people with weak immune systems (like children or elderly) can now easily recover from bacterial infections. However, bacteria are becoming resistant to antibiotics, which was also predicted by Fleming in 1945, during his acceptance speech for the Nobel Prize. 


\section{PATHOGEN}

A microorganism that invades the body and cause an infection

\section{PETRI DISH}

A glass or plastic dish with a lid used to culture living cells.

\section{BACTERIAL}

COLONY

Group of bacterial cells growing together on the surface of a solid medium that are visible to the naked eye.

\section{TINY FOES AND FRIENDS}

Bacteria are very important for us. They live on us and inside us, and we use them to obtain certain nutrients from food, among many other things (Read more in this Young Minds article; We Are Never Alone: Living with the Human Microbiota [1]). But some bacteria, called pathogens, can also cause infections and some pathogens can be very dangerous. Pathogenic bacteria are one of the main subjects of microbiology [2], which is the study of microorganisms: tiny forms of life that cannot be seen by the naked eye. Microbiologists have been facing the same questions since bacteria were discovered. How do bacteria infect humans, and most importantly, is there anything that can be done to stop them?

An individual bacterium can only be seen with a microscope. However, most bacteria grow well in an environment with lots of nutrients, and broths very rich in nutrients (also known as liquid medium) can be used to grow bacteria [2]. If a test tube with sterile broth and a tiny number of bacteria in it is incubated at a certain temperature, the liquid will become cloudy in a matter of hours and it may even change in color. If a jelly-like substance is added to the broth, and the mixture is heated to melt the jelly, this substance can then be poured on plates (also known as Petri dishes) to cool down, you will get a nutrient-rich jelly also known as solid medium. Bacteria can be cultured on the surface of a solid medium. If we add enough bacteria, they will cover the entire surface of the nutrient-rich jelly. If the bacteria are diluted and spread out enough on the plate, an individual bacterium will replicate so much that it will eventually produce a large group of bacteria visible by the naked eye, which we call a bacterial colony. If the original source of bacteria contained more than one type, colonies of different kinds of bacteria might be growing on the solid medium. When we touch just one of those colonies with a sterile object and pass the bacteria to a sterile liquid or solid medium, we can produce a pure culture, which should only contain one type of bacteria [2]. Routinely, microbiologists work with pure cultures to be able to reach clear conclusions from their experiments with a single type of bacteria. However, if their work is not done in sterile conditions, the tubes and plates may become contaminated by other bacteria or even some microscopic fungi living in the environment. If that happens, most microbiologists discard that culture and start again. But Fleming was different from most microbiologists.

\section{AN ACCIDENT WAITING TO HAPPEN...}

On the morning of Monday, September 3, 1928, Fleming was coming back from a family holiday [3]. Before he went on holiday, Fleming was working with a very common pathogen: Staphylococcus aureus. Fleming left some glass Petri dishes on his lab bench, with these bacteria growing on the surface of solid medium. Usually, these plates 
Figure 1

(A) Sir Alexander Fleming at his laboratory bench in London (1943). (B) Fleming observed that a colony of a fungus (Penicillum notatum) contaminated a Petri dish that was inoculated with $S$. aureus, a dangerous bacterial pathogen. Interestingly, S. aureus was unable to grow in the area surrounding the colony of $P$. notatum. Fleming deduced that the fungus was producing something that killed $S$. aureus in the zone of inhibition.

\section{ZONE OF}

INHIBITION

Area surrounding the source of an antibiotic in which bacterial colonies do not grow.

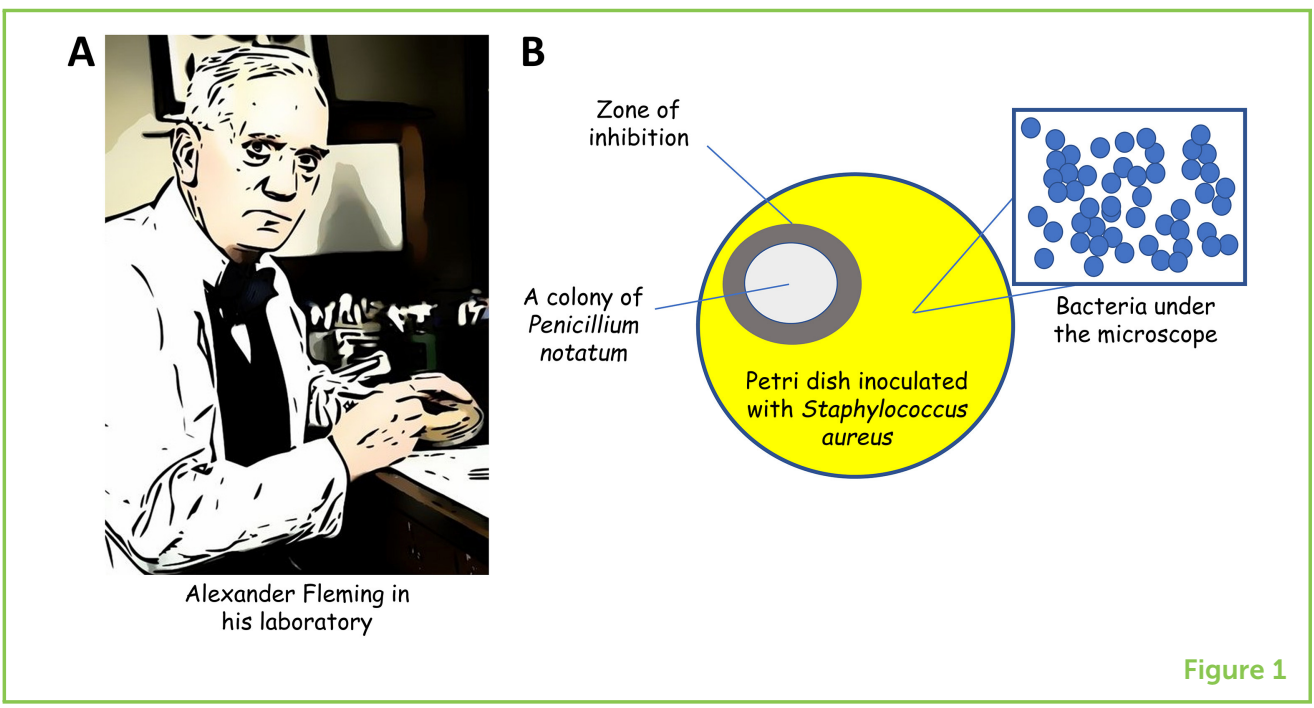

would be sterilized by a laboratory technician to reuse them in other experiments. However, Fleming always had a final look at all his experiments before discarding them, even if they were kept for weeks on the bench (Figure 1A). He would randomly pull samples from the stack of plates to see if anything interesting happened during the last few weeks. Because his laboratory was quite primitive, Fleming would commonly have contaminations on his plates, which were often caused by yeasts and molds from the environment. But one plate looked very different, and when he noticed that plate, he famously said "That is funny...." The plate had been inoculated with a dense culture of bacteria, but it was also contaminated with a microscopic fungus that created a big colony on the side of the plate. What was unusual was that the bacteria were not able to grow in the area close to the fungus colony. There was a perfectly visible area surrounding the fungus that was completely free of bacteria; today, we call this a zone of inhibition (Figure 1B). Therefore, Fleming discovered that a fungus (Penicillium notatum) was producing something that killed Staphylococcus aureus, a dangerous pathogen. Fleming had just discovered an antibiotic, and at first, he called this "mold juice" [3].

At that time, neither Fleming nor his colleagues thought that this discovery could have any real importance, and the actual importance was only demonstrated more than a decade later. However, Fleming had just discovered the biological warfare that exists between different microorganisms fighting for space in an environment rich in nutrients [2]. Fleming did not create penicillin, he observed that a colony of a microscopic fungus produced penicillin as a way to compete with bacteria for the nutrients on an almost-discarded plate. Since then, microbiologists have searched in nature for new antibiotics, to test whether any other microorganisms can produce antibiotics, and this approach has been very successful. Once a new antimicrobial substance is identified, that substance is purified and may be chemically modified to make it easier to produce the new antibiotic 
in large quantities, or to create new versions of the original substance. We are still looking for new antibiotics, and anyone can be part of this through initiatives like "Swab and Send" [4].

\section{HOW DOES PENICILLIN WORK?}

The way that penicillin works to inhibit bacterial growth was not understood until 1980. Now we know that penicillin inhibits the activity of certain enzymes in bacteria called penicillin-binding proteins (PBPs), which are essential for most bacteria to create a wall that covers their cells. Without that wall, bacterial cells are much more exposed the environment, and they may die very easily when the environment changes. In the presence of penicillin, bacteria cannot produce this cell wall to protect themselves, and they die. Penicillin is part of a family of similar antibiotics called the $\beta$-lactams, and many bacteria become resistant to $\beta$-lactams either by producing enzymes that degrade these antibiotics or by acquiring modified versions of the PBPs that do not bind to penicillin any more [2].

\section{THE RESISTANCE IS RISING...}

What Fleming also predicted during his speech accepting the Nobel Prize in 1945 was that bacteria may become resistant to antibiotics. This is just happening due to evolution, because bacteria can adapt very quickly to overcome any hurdle limiting their growth. The changes that help bacteria to adapt may be driven by random mutations in their DNA, and the process is really fast-you can almost see this happening in real time! [5]. In addition, many of the microorganisms producing antibiotics also have genes that make them resistant to those antibiotics. Bacteria are very good at acquiring DNA from other organisms, to get new abilities. This is called horizontal gene transfer [2]. If pathogenic bacteria acquire the genes to make them resistant to a specific antibiotic, that antibiotic becomes useless in the clinic. To prevent antibiotic resistance, antibiotics should only be used when needed (for instance, viruses cannot be killed by antibiotics, so they should not be taken for viral infections), the correct dose should be used (because too low of a dose may help create resistant strains), and we should take antibiotics for the entire time they are prescribed, to make sure to kill all the bacteria causing the infection. If we do not take these steps, we might be helping the spread of antibiotic resistance, and this is a huge problem. In fact, the most dangerous bacterial pathogens are becoming resistant to many antibiotics [2]. Drug manufacturing companies are losing interest in developing new antibiotics, because these drugs may not be profitable as antibiotic resistance grows. Consequently, the rate at which new antibiotics are discovered is not fast enough to cope with the emergence of new, antibiotic-resistant pathogens. We may soon 
go back to a pre-antibiotic era, in which people infected with bacteria could not be treated effectively.

\section{CONCLUSION}

The discovery of penicillin was only possible in a laboratory where contaminations were common. Chance certainly played a role in the discovery of the first antibiotic, but the training and laboratory practice of Fleming were essential for him to identify one of the most important drugs in human history. Unfortunately, due to antibiotic resistance, microbiologists are in a race with bacterial pathogens to find new ways to treat infections. Today, we have a better understanding of how pathogens interact with their hosts, how antimicrobials work, and what the mechanisms of antibiotic resistance are. But, even 90 years after the discovery of penicillin, there is still much more work needed to combat the current antibiotic crisis. You can be part of this by participating in the Swab and Send initiative!

\section{REFERENCES}

1. Da Silva, G., and Domingues, S. 2017. We are never alone: living with the human microbiota. Front. Young Minds 5:35. doi: 10.3389/frym.2017.00035

2. Madigan, T. M., Bender, K. S., Buckley, D. H., Sattley, W. M., and Stahl, D. A. 2018. Brock Biology of Microorganisms. 15th Edn. London: Pearson.

3. Brown, K. 2017. Penicillin Man, Alexander Fleming and the Antibiotic Revolution. Cheltenham: The History Press.

4. Swab and Send Initiative. Available online at: https://www.lstmed.ac.uk/public-engagement/swab-send

5. Kishony, R. 2016. The Evolution of Bacteria on a "Mega-Plate" Petri Dish. Available online at: https://commons.wikimedia.org/wiki/File:Kishony_lab-The_ Evolution_of_Bacteria_on_a_Mega-Plate.webm

SUBMITTED: 30 August 2019; ACCEPTED: 17 December 2019; PUBLISHED ONLINE: 21 January 2020.

EDITED BY: Bahtiyar Yilmaz, Bern University Hospital, Switzerland

CITATION: Letek M (2020) Alexander Fleming, The Discoverer of the Antibiotic Effects of Penicillin. Front. Young Minds 7:159. doi: 10.3389/frym.2019.00159

CONFLICT OF INTEREST: The author declares that the research was conducted in the absence of any commercial or financial relationships that could be construed as a potential conflict of interest.

COPYRIGHT (c) 2020 Letek. This is an open-access article distributed under the terms of the Creative Commons Attribution License (CC BY). The use, distribution or reproduction in other forums is permitted, provided the original author(s) and the copyright owner(s) are credited and that the original publication in this journal 

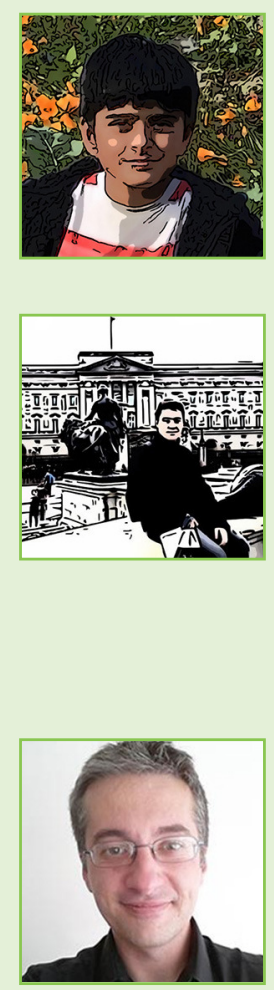

is cited, in accordance with accepted academic practice. No use, distribution or reproduction is permitted which does not comply with these terms.

\section{YOUNG REVIEWERS}

\section{ANJISHNU, AGE: 12}

Hello, my name is Anjishnu and I am in sixth grade. I live in San Diego and I have a passion in writing, reading, math, and science. I also like reading about cars and other vehicles. I enjoy playing tennis and guitar. I want to be an aeronautical engineer when I grow up and would like to design planes that will make flying safer.

\section{ENZO, AGE: 15}

Enzo is currently coursing the first year of High School. He is planning to study Computational Engineering at college. He is fascinating by the English culture and has visited many places in the United Kingdom. He was aware of Fleming's discovery, and visited the Fleming museum in London.

\section{AUTHOR}

\section{MICHAL LETEK}

My research work has always been focused on identifying new ways to control bacterial pathogens. Over the last few years, I have studied how bacteria grow and divide, how they interact with their host during infection, and the host response to bacterial infection. My aim is to find novel therapies to control bacterial pathogens and to understand what makes us susceptible to infections caused by microorganisms, such as Staphylococcus aureus or Mycobacterium tuberculosis. *michal.letek@unileon.es

†Present address: Department of Molecular Biology, Area of Microbiology, University of León, León, Spain 